\title{
THE PECULIARITIES OF A FEMALE PROTAGONIST IN A. BRONTË'S EPISTOLARY NOVEL
}

Juan de Dios Torralbo Caballero, University of Cordoba, Spain, 122tocaj@uco.es

Violeta Janulevičiene, Mykolas Romeris University, Lithuania, vjanul@mruni.eu

\begin{abstract}
This paper offers a study of the less known today and less analysed epistolary novel by Anne Brontë's The Tenant of Wildfell Hall. It focuses on the instances of female protagonist's unconventional behaviour according to the existing societal norms of the Victorian era. The research aims at pointing out the reasons modifying heroine's behaviour and analysis of the reactions that the protagonist's acts of nonconformity elicits in other characters of the novel. The undertaken study is believed to raise awareness of less studied Brontë sisters works in university literature and gender studies courses, as it touches upon the emerging issues of the female strength in the Victorian society.
\end{abstract}

Keywords: Anne Brontë, female protagonist, acts of nonconformity.

\section{INTRODUCTION}

Anne Brontë (1820-1849) was and still is overshadowed by her sisters in the literary analysis and literature studies. Emily and Charlotte Brontës have a well-established status in the English literary canon while Anne's works are only briefly mentioned if not completely ignored. In the non-English spoken university literature studies, to the best of the authors' knowledge, Anne Brontë's works are scarcely analysed, if at all. However, with expressed social changes and gender studies gaining power, the interest in her works has resurged and the need to fill in the gap on all the Brontës creations is considered important. The literary critics (e.g. Berry, Bullock, Colon, Gardner, Gérin) have been revisiting Anne Brontë's works finding them more complex than has been previously thought, written in a pre-feminist innovative style, consciously different from her sisters' novels. The latest studies in recent years by S. Ellis (2017) and N. Holland (2016) offer a re-evaluation of $A$. Brontë's creations as a writer ahead of her time who has much to say on dignified female strength. The storyline of the second A. Brontë's book The Tenant of Wildfell Hall has been 
reworked, appearing in The Woman Who Ran, by S. Baker, and the BBC production, this alone demonstrating the novel's lasting impact.

However, at the time of the publication both A. Brontë's novels- Agnes Grey and The Tenant of Wildfell Hall received a great deal of critical attention due to the realistic depiction of immoral behaviour of Victorian upper-class.

Her second novel The Tenant of Wildfell Hall upon the publication was deemed as scandalous, owing to its unsoftened picture of alcohol abuse and adultery through depicting debauchery and degradation of the heroine's husband whom she flees. The novel was published in three volumes in 1848 under the pseudonym Acton Bell.

The Tenant of Wildfell Hall is an epistolary novel. The present study covers the fifteen letters that Gilbert Markham writes and sends to his brother-in-law J. Halford, which comprise the first fifteen chapters of the novel. The beginning of the narrative in the novel refers to the fall of 1827, and the first part of the novel is fully comprehended in the light of subsequent chapters. For example, the events described in the second part of the novel, namely, forty-third chapter, only then shed light on the fact that Helen Graham is the same person as Helen Huntingdon, and the motives of her decision to leave the husband, taking her son Arthur with her, are given. The explanation is also offered for her name change, self-protectively assumed, but done on her own account that is not approved by the societal norms of the time:

"The name upon the cards was Mrs. Graham, which appellation I mean henceforth to adopt. My mother's maiden name was Graham, and therefore I fancy I have some claim to it, and prefer it to any other, except my own, which I dare not resume" (Brontë, 2008: 329).

Thus, the story that commences of Helen Graham (exHuntingdon) beginning her new life with her son, posing as a widow, falls into an integrated framework only later in the layered narrative.

This given study centres on Helen Graham - the novel protagonist. It aims at pointing out the reasons modifying her behaviour which clash with the moral norms of the time the novel was written, i.e. Victorian era (Hughes, 2014). The paper also examines the reactions that Helen Graham's unconventional behaviour elicits in other characters of the novel. The topicality of the aim is determined by the emerging recognition of the pre-feminist elements depicted in the novel by Anne Brontë.

To achieve the aim set above the following objectives are to be met: 1) to identify, describe and group instances of the peculiar 
behaviour of the female protagonist in the novel 2) to verify in the reference material available (http://victorian-era.org/victorian-eramorality; "19century gender behaviour and etiquette" on the British Library site www.bl.uk/discovering-literature) if the described acts were unconventional to the social norms of the Victorian era; 3) to point out what reactions and feelings those unconventional acts of the heroine elicit in the immediate social circumstances.

The methodology of the research is based on qualitative approach. The main methods of the research are descriptive and analytical as only most significant or recurrent patterns of peculiar to the protagonist behaviour are presented as illustrative examples.

The theoretical and practical value of the present study is determined by the innovative reading of the less studied Anne Brontë's novel, highlighting the new, not yet approved by the society behavioural patterns of female character. It is hoped to contribute to the awareness of the works of a less studied works of Brontë sisters and the issues of the female strength in the Victorian society raised. The results of the reach can be used for the teaching of university literature and gender studies courses.

\section{OVERPROTECTION OF THE SON}

A recurring theme is Helen Graham's vigilant care for her son, which goes against the prevalent view-point of the Victorian society. According to the information given in https://victorianchildren.org/victorian-children-in-victorian-times/, "Wealthy Victorian Children rarely communicated with their parents except for a specified time each day." The references cite Winston Churchill, who is reported to say that he could "count the times he had been hugged by his mother" as a child").

The second chapter of the novel features a scene that reveals Helen's excessive zeal in this regard, when Gilbert Markham approaches Wildfell Hall and the female protagonist's son Arthur cheerfully attempts to approach Markham's dog, but becomes snagged on a cherry tree when jumping from the garden wall. By the time his mother appears Arthur is already petting the dog. Helen over-reacts to the situation and accosts Gilbert by rebuking him:

"Give me the child! she said in a voice scarce louder than a whisper, but with a tone of startling vehemence, and, seizing the boy, she snatched him from me, as if some dire contamination were in my touch, and then stood with one hand firmly clasping his, the other on his shoulder, fixing upon me her large, luminous, dark eyes -pale, breathless, quivering with agitation". (ibid, 22) 
Though Gilbert Markham explains to Helen that he did not intend harming the child ("he was tumbling off the wall there and I was so fortunate as to catch him, while he hung suspended headlong"), Helen cannot be reassured. The heroine subsequently expresses (in the third chapter, during her visit to Mrs. Markham) that she never leaves her son alone, as "he is my only treasure; and I am his only friend, so we don't like to be separated" (ibid, 25). This confirmation also serves her as an excuse for not visiting the Millwards or Mrs Wilson. The reaction of her interlocutor, Mrs. Markham, indicts Helen's abnormal behaviour, pejoratively defined as follows: "I call that doting [...] such foolish fondness, as well as to save your son from ruin as yourself from ridiculous" (ibid, 25). In the opinion of others, overprotection would have the negative consequences on the child's future.

Another instance of excessive, according to the norms of the time, protection appears in Chapter 6, when Gilbert Markham encounters the two of them walking, and mounts the child on his horse. Here, an ever presence of the mother is highlighted with the reason not only to ensure the son's safe conduct, abut "to see that I [G. Markham] instilled no objectionable notions into his infant mind; for she was ever on the watch, and never would allow him to be taken out of her sight" (ibid, 44).

In another encounter, when Gilbert Markham spots the mother painting and approaches her, the young man accompanies Arthur on a walk, this being the first time that Helen Graham would allow it, but upon their returning "she seemed rather displeased at any keeping him long. She had shut up her sketch-book, and been, probably, for some minutes, impatiently waiting his return" (ibid, 47).

There are other instances in the novel in which the mother exhibits concern when her son is not in her company. Previously, while Helen was still with her husband, Arthur Huntingdon, her son goes out with a friend of his mother's, Esther Hargrave, to the hall and garden, to run a race, at which point his mother shows signs of concern in this way: "He, somewhat to my discomfort, enticed her from the room to have a run in the hall; and, thence into the garden" (ibid, 280).

These episodes manifest the excessive protectiveness of Helen Graham's for her son Arthur, whom she does not allow to be alone, or to stray from her. The protagonist is afraid that the child would suffer an accident, or that he might be kidnapped and taken away from her. Anne Brontë skilfully reveals through these and similar episodes the unconventional behaviour to the norms of the time and the protagonist's constant feelings of insecurity and precarious state. 


\section{THE HYPOCRITICAL VICTORIAN ALCOHOL-RELATED ATTITUDES}

It is a common knowledge that a façade of sobriety, sternness and piety was adopted while turning a blind eye to the many evils that were rampant in Victorian England.

In the third chapter an eloquent incident is depicted while Mrs Graham visits the Markham house Linden-Car. ${ }^{1}$ The lady of the house Mrs Markham asks her daughter Rosa to serve some wine. At the mere mention and sight of the beverage, young Arthur reacts shockingly with terror and dread: "Arthur especially shrank from the ruby nectar as if in terror and disgust and was ready to cry when urged to take it" (ibid, 27). His mother clarifies that the boy detests the very sight of wine and that "the smell of it almost makes him sick" (ibid, 27).

The boy's mother, instead of openly pointing out that the boy's aversion to wine stems from previous, traumatic experiences involving his alcoholic father, apologises by explaining that she used to administer "a little wine or weak spirits-and -water, by way of medicine when he was sick, and, in fact, I have done what I could to make him hate them" (ibid,27).

In reality, the abuse that Helen has suffered and left indelible effect on her begins after her husband Arthur had drunk excessively. Both he and his wife recognise and confirm his alcoholism. In Chapter 27 the husband offers justification for flirting with Annabella at the party with the following words: "I had taken too much wine, and I was scarcely myself, at the time", to which Helen responds that "You often take too much; -and that is another practice I detest" (ibid., 198). In Chapter 36 the protagonist derides her husband's addiction as "the sottish indulgence of his sensual appetites" (ibid., 274).

It is only in the final chapters of the layered narrative that the true reason for this alcohol aversion is revealed: the boy, little Arthur, used to drink with his father and his father's companions. The child's aversion to alcoholic beverages is best appreciated in Chapter 41, when the mother (with a medication of the time called "tartaremetic") manages to purge from the child the vice that his father had instilled. Helen achievement is presented in the following way: "... since I have declared that the taste, the smell, the sight of any one of them is sufficient to make him sick, I have given up teasing him about them» (ibid.,314). Helen succeeds in an unconventional way by giving

1 a "car" denotes here a different concept: in a northern dialect the word means pond or low-lying boggy ground. http://www.oxfordreference.com 
her son wine and even water with brandy or gin until the child abhors all alcoholic beverages. The mother even wielded alcohol as a threat in this way: "except now and then as objects of terror in cases of misbehaviour: "Arthur, if you're not a good boy I shall give you a glass of wine". (ibid.,314).

Helen reminds her husband of his vice, and the consequences it will entail if he does not desist from it, and when she openly indicates how he, as a father, has inculcated the vice in his son, the authoress is highlighting an issue that was a total taboo in Victorian society families. The protagonist herself states that she was much ashamed to refer to alcohol abuse openly previously in the novel: "I never mentioned it before, because I was ashamed to do so; but now $I^{\prime} l l$ tell you that it distresses me, and may disgust me, if you go on and suffer the habit to grow upon you, as it will, if you don't check it in time". (ibid., 198).

In the first part of the novel the mother, Helen, proclaims that: "By that means I hope to save him from one degrading vice at least. I wish I could render the incentives to every other equally innoxious in his case." (ibid., 27). The conversation then again leads to a metaphorical dialogue about virtue, the path of life, stones and hurdles. Mrs Markham's reaction, in response to Helen's stringent prevention, is a premonition that such a treatment of the boy will spoil his spirit and would have an effeminate effect on the boy. She evokes two eloquent natural images:

"[...] it is better to arm and strengthen your hero, than to disarm and enfeeble the foe; -and if you were to rear an oak sapling in a hothouse, tending it carefully night and day, and shielding it from every breath of wind, you could not expect it to become a Hardy tree, like that which has grown up on the mountain-side, exposed to all the action of the elements, and not even sheltered from the shock of the tempest". (ibid., 29).

The contrastive metaphors of the greenhouse plant (a feeble oak attended to in a greenhouse) and the robust tree grown in the open reveal Mrs Markham's (and the prevalent view-point of the Victorian society) surprise at an unconventional Helen Graham's behaviour towards her son, and point to two different models for the upbringing of children: one that is overprotective and debilitating, and another that embraces storms and rough weather, as it were, thereby strengthening the child. 


\section{THE AVOIDANCE OF RELATIONSHIP AND SOCIETY APPROVED MARRIED STATUS}

As the British library sources on "19century gender behaviour and etiquette" indicate, J.S.Mill, the philosopher and political economist, in his essay "The Subjection of Women", published in 1869, stresses that a "married woman is not a separate legal entity from her husband, and any property or money she owns comes under his governance". In that light, the heroine of the novel exhibits other acts of unconventional behaviour and reactions that reveal her inner life, mind and thoughts, as she shuns from possible relationship and does not wish to be wooed and have any attachment to men. One of the cases is at the end of the ninth chapter when Gilbert Markham offers to accompany Helen to Wildfell Hall after visiting his house. She spurns his company firmly. The female protagonist's brother (a kinship of which the other characters are not yet aware) is categorical when he states that: "only let me tell you, Markham, that if you have any designs in that quarter they will certainly fail" (ibid., 75-76).

Helen Graham's peculiarities are also mentioned by other characters in the novel. For example, Mrs Markham, when they leave the party at her home, says "Well! I always thought there was something odd about her" and reflects, in front of her children Gilbert, Fergus and Rose as follows: "I misdoubted that appearance of mystery from the very first - I thought there would no good come of it; but it is sad, sad business, to be sure!" (ibid., 76).

The episode in which Helen gives Gilbert a bud of a flower for his sister Rose is meaningful in several ways, as another Victorian maxim proscribed verbal or written communication of sexual feelings, therefore, people instead used the language of flowers. The author of the novel reveals through tangible and manifest details (heroine's expression, smile, the joy on her face, etc.) that Helen is, in fact, in love with Gilbert; and, secondly, it demonstrates that she wants to prevent, at all costs, their friendship from progressing to a romantic relationship. The adversative conjunction signals the turning point:

"[...] she plucked a beautiful half open bud and bade me give it to Rose.

"May I not keep it myself?" I asked.

"No; but here is another for you".

Instead of taking it quietly, I likewise took the hand that offered it, and looked into her face.

She let me hold it for a moment, and I saw a flash of ecstatic brilliance in her eye, a glow of 
glad excitement on her face -I thought my hour of victory was come- but instantly a painful

recollection seemed to flash upon her; a cloud of anguish darkened her brow, a marble

paleness blanched her cheek and lip; there seemed a moment of inward conflict, -and with a

sudden effort, she withdrew her hand, and retreated a step or two back". (ibid., 78)

After this thought, described by the narrator (and the character) in this scene, Helen's later words are: "Now, Mr. Markham [...] I must tell you plainly, that I cannot do with this" (ibid., 78). Helen's candour and expressive clarity, enhanced by the adverb, the two modal verbs, and the negative particle, pique the reader's curiosity about the protagonist's strange conduct, her past, and what she is hiding. When Gilbert inquires if this is due to "some rash vow", Helen replies that "It is something of the kind [...] some day I may tell you", which renders some clarity for both Mr Markham and the reader.

In Chapter 11, when Gilbert and Helen as friends agree to address each other by first names, she feels "unhappy and dissatisfied with herself" and he says "I often felt myself a most confounded hypocrite with it all" (ibid., 80). Hence, Gilbert's conclusion contains an understatement typical of the sentimental novel.

Helen's conflicted resolution not to fall in love and not to start a new conjugal life is illustrated in the twelfth chapter episode where Gilbert asks her bluntly "Do you love me?" to which she responds: "I will not answer it". This scene constitutes an explicit declaration of love, an overt proposal by Gilbert, and an implicit confirmation by Helen: "She turned from me to hide the emotion she could not quite control" (ibid., 89). In the thirteenth chapter Gilbert Markham's infatuation is elaborated through the mention of sharp Cupid's arrows. The metaphor of Cupid's arrows unifies the references and points to Helen's determined elusion of romantic relation, which goes against the society-approved pressure to marry and "belong" to a man (cf. Calder). During the Victorian era, for middle and upper-class women, marriage was an expected status and even duty. Furthermore, the society of that time did not approve of women earning their own living and prevented the females being independent.

\section{EARNING THE LIVING BY HERSELF}

The prevailing pressure on the necessity to marry incurred that women were condemned to a life inescapably dependent on a man's 
income. However, the heroine of the The Tenant of Wildfell Hall, contrary to that societal expectation, takes efforts to earn the living all by herself, even if that means staying in the underrun house. The author of the letters, Gilbert Markham, describes the isolation of the dreary Elizabethan house, perched on a rugged and dismal peak, two miles from the Markham house. He also portrays the dark colours of its stones and its coldness at the opening of the second chapter. In Chapter 12, when Gilbert Markham shows up in haste, after the vicar's chastising of Helen, the narrator describes the house's coldness, mirroring and intensified by the sadness and agitation of the female protagonist, who had "a bitter laugh [...] in a tone of mournful resignation" (ibid., 85). The writer suggests, in this way, a symbiosis between the state of the protagonist and that of the surrounding elements. From the beginning of the novel, the sense of sanctuary she feels in the abandoned and isolated house where she lives is evident, but this security is marred by the other characters' ill talk of the lonely "widow". At the beginning of Chapter 7 when Fergus, Rose, Eliza and Gilbert visit Helen, Fergus, amongst other impertinent questions, asks for the reasons of choosing such a dilapidated place for living. The protagonist explains that she enjoys the solitude, prefers the absence of any human activity, and that the Gothic elements that Fergus indicates actually please her. When Fergus persists in his questioning of the new neighbour, Helen Graham does not wish to reveal her past, although her obsession with it (as well as her fear of being discovered and found by her husband) figure prominently throughout these chapters.

The protagonist, therefore, seeks and builds a new life at Wildfell Hall. For her this new, solitary and isolated life means finding a way to stand on her own two feet, which she does through painting. Helen paints works that she sells in London (indicating a false location and initials, to keep from being found). She appreciates the opportunity she enjoys, as a woman artist, to earn a living: "Well, after all, I should not complain: perhaps few people gain their livelihood with so much pleasure in their toil as I do" (ibid., 74).

Paid work for middle-class women was frowned upon by the society. Therefore, the heroine, this autonomous and independent character, is frowned upon by the other characters in the novel. Early in Chapter 11 Rose Markham states that "mamma says, if she were a $p$ $r$ o $p$ e $r$ person, she would not be living there by herself" (ibid., 74), reminding readers of the protagonist's solitary character, as she lives in isolation, of her volition, at Wildfell Hall, thus, again, not conforming to the societal conventions. 


\section{PROTAGONIST'S ANGUISH DETERMINED BY NON- SUPPORTIVE SOCIETAL ATTITUDE}

Going against the society approved norms and rules takes its toll. In Chapter 7, Helen and her son Arthur, Gilbert Markham, Rose Markham, Fergus Markham, Richard Wilson and Eliza Millward and Mary Millward go on an outing to enjoy views of the sea. As Helen is sitting, drawing, alone by the reef, at the edge of a cliff, Gilbert Markham gets up and moves away from the group to approach her, which frightens her: "the falling of my shadow across her paper, gave her an electric start; and she looked hastily round" (ibid., 58). This reaction reveals how Helen is always in a state of alert, after fleeing from Crossdale to Wildfell Hall to escape from her abusive and philandering husband. Moreover, the protagonist herself expresses that her mind is dominated by the contemplation of a single object. She could not count on the good sense of others when in need. These references reveal her past and her apprehension towards her husband, Arthur Huntingdon, whose prolonged visits to London were frequent, as his alcoholism and debauchery became even more pronounced during Helen's pregnancy. The problem she had at home was so great that this "object", her husband and his lifestyle, his mistreatment and abuse of her, prevented her from being able to make other judgments, such that she could not trust her common sense herself.

Helen's inner state has deteriorated so far that the protagonist tells Gilbert, in the middle of the fifteenth chapter, that "[...] smiles and tears are so alike with me; they are neither of them confined to any particular feelings: I often cry when I am happy, and smile when I am sad" (ibid., 109). Naturally, her psychological anguish is reflected in her modus vivendi and causes her to exhibit the peculiarities thus far indicated. In view of her past, the reader is led to understand her oddities. According to several sources on the customs and laws of the Victorian era, a woman who wanted to divorce her husband, however, had to prove adultery and show it had been aggravated by desertion or cruelty. A wife could not claim damages from the third party. This difference was not legally rectified until 1923 (cf. https://valmcbeath.com/victorian-era-womens-rights/\#.XRJUEuj7Q2y). Therefore, Helen's anguish, caused by shaky social status is depicted with great realism in the numerous episodes of the novel. 


\section{SOCIETAL DISAPPROVAL OF THE HEROINE'S ACTS OF NONCONFORMITY}

The defined acts of non-conformity with the social and moral norms of the time meet a rather expressed disregard towards the female protagonist of the novel. Helen Graham's disrepute among her neighbours is expressed in several instances, one of them when they attend the party at the Markhams' house (Chapter 9) and Miss Wilson does not wish to sit by Helen's side inquiring whether she had any husband at all. Another example is Eliza Millward criticising Helen in front of Gilbert Markham and referring to the gossip surrounding the heroine. In the same Chapter 9, Gilbert Markham reflects on Helen's detractors and the unjust slander besmirching her and her son's reputation.

Gilbert Markham reflects on the impediment to his happiness again in Chapter 12: "this hateful barrier, this mysterious impediment to my happiness" (ibid., 87). Then he calls it "the obstacle to our union", reinforcing the strongly constructed semantic field frustrating his happiness: "it is demolished, and you must -you shall be mine!" (ibid., 88).

During Gilbert's preparations to visit Helen in Chapter 11, his sister Rose admonishes him against calling upon her so often. Later on in Chapter 12 we find Helen Graham in her solitary room, pacing back and forth, and reflecting, evidencing a certain parallelism with the above. In this case she is ruminating on the vicar's admonishment for her during his visit (at the end of the previous chapter). Gilbert Markham is quick to succour her, as she is restless, discouraged and sad. Gilbert indicates the cause of the protagonist's affliction with the following pejorative image: "the wickedness of the world" (ibid., 85), thus exonerating Helen and blaming the world, external agents, slander, and the apparent conspiracy against her. In the dialogue between them, Gilbert dismisses the criticisms as "some detestable falsehoods". Helen's response summarises and elaborates on the gossip plaguing her, which stains her as dishonest, hypocritical and dissolute -precisely the vices of which she disapproves:

"I did not think Mr Millward a fool, and he believes it all; but however little you may value

the opinions of those about you -how-ever little you may esteem them as individuals, it is not

pleasant to be looked upon as a liar and a hypocrite, to be thought to practice what you abhor, 
and to encourage the vices you would discountenance, to find your good intentions frustrated,

and your hands crippled by your supposed unworthiness, and to bring disgrace on the

principles you profess". (ibid., 87)

Special attention should be paid to the metaphor of hands mutilated by indignity used. This image of a maimed body enforces the comprehension that her freedom and intentions to build a new life at Wildfell Hall are restricted.

Gilbert Markham's fine reputation contrasts the female protagonist's with the widespread contempt towards her: "Are you a hero enough to unite yourself to one whom you know to be suspected and despised by all around you...? (ibid., 88). Thus, A. Brontë emphasises that Helen has lost her good name in Victorian society, which constitutes an impediment to her living her life freely and pursuing happiness. The conceptualisation of Gilbert as a hero allows us to infer an indirect reference to the novel typical of the era, in which the female protagonist's honour is usually immaculate, and any tarnishing of it is a devastating social handicap.

Helen states that "I have no crime to confess; but I have more than you will like to hear" (ibid., 89). This reply serves to portray a protagonist who is fleeing from an abusive husband, a determined woman convinced of her redeeming qualities, who considers her escape (note the direct object of the verb, denied with categorical clarity: no crime) as an action necessary to lead a decent life, and obtain her freedom.

The unfolding of events, the gradual revelation of her past, is a layered narrative technique masterfully employed by Anne Brontë, as the reader reaches the end of the first part and still does not know with certainty the reasons for Helen's unusual behaviour and strange reactions. Uncertainty and expectation also surround the male protagonist of the first part, Gilbert Markham, who has not yet cleared up the questions that assail him, aggravated by the slander. At the end of Chapter 15 we find Gilbert Markham anxiously reading Helen's diary, such that the questions and suspicions he harboured are, ostensibly, resolved - although this is not explicitly stated in the text. Nick Holland (2016:186) calls this a "[...] a suspense-filled opening that will have readers guessing: will this be a romance, a mystery novel or even a gothic horror?"

Helen, in a great state of agitation, strongly wishes for Gilbert to know the truth, so she tears a few pages from her diary, and hands them to Gilbert: 
"She did not speak, but flew to her desk, and snatching thence what seemed a thick album or manuscript volume, hastily tore away a few leaves from the end, and thrust the rest into my hand, saying 'You needn't read it all; but take it home with you', [...]" (ibid., 109).

There is a transition between the fifteenth and the sixteenth chapters where the shift in narrative terms from a first-person male to a first-person female narrative, from Gilbert Markham to Helen, appears. Based on what Gilbert writes to Halford, it is concluded that Helen's narrative, despite being expressed by her in the first person, is filtered through Gilbert's perspective.

Thereafter, the layered narrative brings us back to a phase of the protagonist's previous life at her uncle's house in the countryside, where she enjoys drawing. This reflection by Helen, appearing later in the novel, but earlier on its timeline, serves as a cohesive element as, on the one hand, it reveals the on-going protagonist's passion for painting and, in addition, introduces another male character Arthur Huntingdon, whom she had married.

Upon their marriage, Helen's husband beats her up and abandons her for long periods of wanton behaviour and revelry in London. After five years of marriage, the period depicted in the beginning of the third volume, Helen announces that she can endure this life no longer (Chapter 37). Though with a profound sense of loneliness and humiliation, strong and brave Helen, resolves to leave her spouse. Helen flees with her son Arthur, to be free and safe from this plight (at the beginning of Chapter 44), stating: "Thank Heaven, I am free and safe at last!" (ibid., 329).

This step towards her new life of freedom, related in these final chapters, links two narratives of different time and closes up the novel. All the events are put in the diachronic perspective and the explanation of Helen's unconventional acts are evident.

\section{CONCLUSION}

Anne Brontë in her epistolary novel The Tenant of Wildfell Hall skilfully draws a non-typical portrait of a heroine who needs solitude and seeks a secluded and discreet self-dependant life, protecting her son. The female protagonist is hiding something of capital importance for her, something affecting her unconventional reactions and behaviour.

The analysis presented in this paper sheds light on the strange female tenant's major peculiarities: 
- Living by herself with a son. A married woman who abandons her husband and takes her son with her constitutes a positively scandalous scenario according to the norms of affluent Victorian society.

- Earning her own living by painting under a pseudonym. This fact again is in non-conformity with the societal norms of the time.

- Overprotecting her "only treasure" - her son, whilst the Victorian era prevailing standards and rules for child upbringing exclude too tight the parent-child bond.

The listed unconventional protagonist's acts do not signal the heroine's weirdness, it rather highlights the perception that the norms of the Victorian society call for unusual actions, that these norms and prejudices incur the pressing desire to change the way of life for preserving personal integrity and basic human values - living an independent, sober, free from physical violence life and caring for the off-springs. The heroine courageously rejects the hypocritical norms of the time in the course of the narrative plot that is driven by a toxic marriage and treachery in it.

The novel is a manifestation of a strong nonconformist woman, holding a mirror up to the society failings and not putting up with lies or pretension. The unconventional acts of a female protagonist in the eyes of the hypocritical society is the statement of true-to-oneself heroine who overcomes misunderstanding, contempt and suppression and is led by the fundamental values of freedom, dignity and selfrespect.

It is in her this second epistolary novel The Tenant of Wildfell Hall that A. Brontë, the youngest of the Brontë sisters, skilfully reveals the hypocricy of the societal norms of the Victorian era and the psychology of the female protagonist, whose actions are re-evaluated in our times from the perspective of gender equality studies.

\section{References:}

Berry, Elizabeth Hollis. "Agnes Grey: 'Pillars of Witness' in 'The Vale of Life". Anne Brontë's Radical Vision: Structures of Consciousness. English Literary Studies. Victory: U of Victoria, 1994.39-90.

Brontë, Anne. The Tenant of Wildfell Hall. Oxford: OUP, 2008.

Bullock, Meghan. "Abuse, silence and solitude in Anne Brontë's The Tenant of Wildfell Hall". Brontë Studies, 29.2 (2004), 135-141.

Calder, Jenni. Women and Marriage in Victorian Fiction. Oxford: OUP, 1976. 
Colón, Christine. "Enacting the Art of Moral Influence: religion and social reform in the works of Anne Brontë". Women's Writing. 11.3 (2004):399-419.

Ellis, Samantha. Take Courage: Anne Brontë and the Art of Life. London: Vintage, 2017.

Gardner, Marilyn Sheridan. "'The food of my life': Agnes Grey at Wellwood House". New Approaches to the Literary Art of Anne Brontë. Ed. Julie Nash and Barbara A. Suess. Hampshire: Aldershot, 2001.45-62.

Gérin, Winifred. Anne Brontë. London: Allen Lane, 1976.

Holland, Nick. In Search of Anne Brontë. Stroud: The History Press, 2016.

Hughes, Kathryn. Gender Roles in the $19^{\text {th }}$ Century. https://www.bl.uk/romantics-and-victorians/articles/genderroles-in-the-19th-century. 2014.

http://victorian-era.org/victorian-era-morality

"19century gender behaviour and etiquette" in www.bl.uk/discovering-literature

https://valmcbeath.com/victorian-era-womens-rights/\#.XRJUEuj7Q2y https://victorianchildren.org/victorian-children-in-victorian-times/ http://www.oxfordreference.com

\section{OSOBENOSTI ŽENSKOG LIKA U EPISTOLARNOM ROMANU E. BRONTE}

Članak nudi analizu manje poznatog i malo analiziranog epistolarnog romana En Bronte Stanar Vildfel Hola. U središtu pažnje je nekonvencionalno ponašanje junakinje koje nije u skladu sa društvenim normama viktorijanske ere. Istraživanje ima za cilj da ukaže na razloge za izmijenjeno ponašanje junakinje $\mathrm{i}$ da anlizira reakcije drugih karaktera u romanu na nekonformističko ponašanje junakinje. Vjerujemo da će ova studija pobuditi interesovanje za ovaj manje proučavani roman Bronteove $u$ okviru univerzitetske nastave književnosti i džender studija, budući da roman dotiče pitanja ženske snage u viktorijanskom društvu.

Ključne riječi: En Bronte, ženski lik, nekonformistički čin. 